$\begin{array}{ll}\text { Research Square } & \begin{array}{l}\text { Preprints are preliminary reports that have not undergone peer review. } \\ \text { They should not be considered conclusive, used to inform clinical practice, } \\ \text { or referenced by the media as validated information. }\end{array}\end{array}$

\title{
Fifteen-Year Survival Of Hepatocellular Carcinoma Extending Into The Right Atrium Treated By Multidisciplinary Therapies Including Surgical Resection Under Cardiopulmonary Bypass: A Case Report And Literature Review
}

\author{
Yoshiro Nishiwaki ( $\nabla$ nlc515@gb3.so-net.ne.jp ) \\ Hamamatsu Medical Center \\ Toshiomi Kusano \\ Tokyo Midtown Clinic \\ Takane Hiraiwa \\ Hamamatsu Medical Center: Hamamatsu Iryo Center \\ Takachika Ozawa \\ Hamamatsu Medical Center: Hamamatsu Iryo Center
}

\section{Case report}

Keywords: Cardiac arrest, Cardiopulmonary bypass, Hepatocellular carcinoma, Multidisciplinary therapies, Right atrium, Thrombectomy, Tumor thrombus

Posted Date: February 9th, 2021

DOI: https://doi.org/10.21203/rs.3.rs-196897/v1

License: (c) (1) This work is licensed under a Creative Commons Attribution 4.0 International License. Read Full License 


\section{Abstract}

Background: Hepatocellular carcinoma (HCC) with tumor thrombus (TT) extending into the right atrium (RA) is rare, and most cases are at an advanced stage with a poor prognosis. We report a case of HCC with TT in the RA (RATT) with 15-year survival.

Case presentation: The patient was a 67-year-old man with a huge HCC with RATT. He developed edema of the lower extremities in November 2002. Then, a liver tumor $6.5 \mathrm{~cm}$ in diameter in hepatic segments 7 and 8 was identified by ultrasonography and computed tomography. Cavo-atrial thrombectomy was performed successfully using cardiopulmonary bypass (CPB) with heparinization and cardiac arrest. After the thrombectomy, right hepatectomy was performed using the hanging maneuver. The right hepatic vein was transected, and the stump was closed with a running suture. The total operation time was $10 \mathrm{~h} 48 \mathrm{~min}$, and the total blood loss was $7267 \mathrm{~mL}$. The patient recovered uneventfully except for right pleural effusion, and he experienced no side effects related to CPB, such as immunosuppression or cerebral infarction. He was cancer-free for approximately 9 years after the surgery. A new lesion in the remnant liver was detected by magnetic resonance imaging in March 2012. He underwent six rounds of transcatheter arterial chemoembolization, followed by sequential administration of sorafenib and sunitinib. Radiation therapy was administered to the remnant liver twice and to the spine after he was diagnosed with bone metastasis. Finally, the patient died 6 years after the recurrence.

Conclusions: Cavo-atrial thrombectomy under CPB prior to hepatectomy for HCC with RATT can be performed safely to prevent major complications related to CPB. Our patient's postoperative clinical course followed by multidisciplinary therapies led to an approximately 15-year survival.

\section{Background}

Hepatocellular carcinoma (HCC) is the fifth most common malignancy worldwide [1]. Tumor thrombus (TT) formation in the hepatic or portal veins is common in advanced-stage HCC [2]. TT extension into the inferior vena cava (IVC) and subsequently into the right atrium (RA) is rare but has a dismal prognosis [3]. The mean postoperative survival period in previous reports from 1998 to 2002 ranged from 7 months to 8 months [4]. However, Wang et al. [5] and Wakayama et al. [6] reported that the median overall survivals of patients who underwent curative resection for HCC with TT of the IVC or RA were 19.0 months and 30.8 months, respectively, since the surgical technique and perioperative management had improved. Although surgical and nonsurgical treatments such as radiofrequency ablation (RFA), transcatheter arterial chemoembolization (TACE), radiotherapy, and systemic chemotherapy have been reported in such cases, the optimal therapeutic management of HCC with IVC or RA thrombi has not been established [6-8]. It is generally assumed that liver resection combined with IVC or RA thrombectomy is the only potentially curative option, but this is a challenging and dangerous procedure that involves a high surgical risk [7]. Here, we report a case of HCC with TT extending into the RA with approximately 15-year survival.

\section{Case Presentation}

A 67-year-old man was referred to our hospital in January 2003 with a chief complaint of edema in the lower extremities since November 2002. He received a blood transfusion when he underwent surgery for gastric ulcer at 39 years of age and was later diagnosed with hepatitis B virus infection. Laboratory tests revealed a normal albumin level $(4.6 \mathrm{~g} / \mathrm{dL})$, normal total bilirubin level $(0.55 \mathrm{mg} / \mathrm{dL})$, normal serum prothrombin time (101.8\%), mildly elevated D-dimer $(2.1$ $\mu \mathrm{g} / \mathrm{mL}$ ), hepatitis B surface antigen positivity, and hepatitis $\mathrm{C}$ virus antibody negativity. The tumor markers a-fetoprotein and protein induced by vitamin $\mathrm{K}$ absence-II were elevated to $135 \mathrm{ng} / \mathrm{mL}$ and $19000 \mathrm{mAU} / \mathrm{mL}$, respectively. The Child-Pugh classification was A, the indocyanine green retention rate at $15 \mathrm{~min}$ was $14 \%$, and the vanishing rate was 0.105 . Contrast-enhanced computed tomography showed a low-density mass $6.5 \mathrm{~cm}$ in diameter in the right liver that was enhanced with contrast medium and a TT extending from the main tumor through the IVC to the RA (Fig. 1a, b). Echocardiography clearly demonstrated a TT in the RA (Fig. 1c). Based on these findings, a diagnosis of HCC in the right liver with TT growth into the RA was made.

Operative technique

Surgery was performed in February 2003 using cardiopulmonary bypass (CPB) with total hepatic vascular exclusion (THVE). First, a reversed L-shaped incision was made in the upper abdomen, and neither intrahepatic metastasis nor peritoneal dissemination was ascertained. Next, a median sternotomy was performed, and the pericardium and diaphragm were divided at the level of the IVC hiatus in the diaphragm. The superior vena cava (SVC) and ascending aorta were exposed and taped. Catheters were inserted into the SVC, IVC via the right femoral vein, ascending aorta, and superior mesenteric vein after intravenous administration of heparin sodium (300 units $/ \mathrm{kg}$ ). Extracorporeal cardiopulmonary bypass was established, with the arterial inflow through a cannula placed in the ascending aorta and drainage from the SVC and IVC. THVE was induced by snaring the SVC, the IVC just below the liver, and the hilar tributaries (Pringle's maneuver). Cardiac arrest was obtained by the infusion of crystalloid cardiac solution after cross-clamping the ascending aorta. Body temperature was controlled at $33.0^{\circ} \mathrm{C}$ by core cooling of the CPB. A longitudinal incision was created in the center of the suprahepatic IVC from the RA. Under direct vision, thrombectomy from the RA to the IVC was successfully performed, and the TT was disconnected from the main tumor (Fig. 2a). Since there was no invasion into the wall of the RA or IVC, the right hepatic vein (RHV) was closed internally without combined resection of the adjacent organ, and the incision over the RA and IVC was closed longitudinally with a running suture. After completing the thrombectomy and de-clamping of the aorta, CPB was stopped, and $3.9 \mathrm{mg} / \mathrm{kg}$ protamine sulfate was administered to neutralize heparin. Then, the right hepatic artery and right portal vein were exposed and ligated, the right liver was mobilized, and right hepatectomy was performed using the hanging maneuver. The RHV was transected, and the stump of the RHV was closed with a running suture (Fig. 2b). Several pieces of tissue adhesive (Tachocomb [Torii Pharmaceutical, Tokyo, Japan]) were attached to the resected liver surface for hemostasis. The CPB time was $82 \mathrm{~min}$. Because additional time was needed to disconnect the TT from the primary tumor because of severe adhesion. The total operation time was $10 \mathrm{~h}$ and $48 \mathrm{~min}$, and the total blood loss was $7267 \mathrm{~mL}$. Most bleeding (approximately $4400 \mathrm{~mL}$ ) occurred during hepatectomy due to heparinization.

Pathology 
The liver main tumor was $7.0 \times 6.5 \times 6.0 \mathrm{~cm}$ in size. Microscopic findings of the resected specimen indicated poorly differentiated HCC, multinodular type and chronic hepatitis, (eg, fc+, fc-inf+, sf+, s0, n0, vp0, vv3, va0, b0, im0, p0, sm-, CH) [9]. The final surgical outcome was pR0 resection of HCC with TT in the RA (Fig. 3a, b, c, d).

Postoperative clinical course

The patient recovered uneventfully except for right pleural effusion, which required drainage. He experienced no side effects related to CPB, such as bleeding, cerebral infarction, or cancer cell dissemination. He was discharged 33 days after surgery and was cancer-free for approximately 9 years after the surgery. In March 2012, magnetic resonance imaging revealed a new lesion in the remnant liver (Fig. 4a, b). As the patient and his family did not desire liver re-resection, TACE was repeated six times until March 2016 (Fig. 4c). Although the patient had a cancer-bearing condition, his daily life was without restrictions. TACE became gradually ineffective, and sorafenib and sunitinib were sequentially administered. In addition, radiotherapy was delivered to the remnant liver in the autumn of 2016 and the summer of 2017. The patient also received radiotherapy to the spine in late summer 2017 because of bone metastasis. Finally, he died of recurrent HCC with bone metastases in January 2018, approximately 15 years after the initial surgery.

\section{Discussion And Conclusions}

HCC with TT in the RA (RATT) should be treated as an oncologic emergency because of the risk of sudden cardiac death and pulmonary embolism. However, there is no consensus on the therapeutic options for HCC with IVC or RA thrombi [6-8]. The practice guidelines of the American Association for the Study of Liver Diseases [10] and the Barcelona Clinic Liver Cancer guidelines [11] recommend sorafenib for advanced HCC, including HCC exhibiting major vascular invasion [12]. However, the prognosis remains unsatisfactory because the survival time is only 8.1 months if major vascular invasion is present [13]. Therefore, the only potentially curative option for HCC with TT in the IVC or RA is liver resection with thrombectomy.

Li et al. [14] classified TT based on the anatomic location relative to the heart. Type I inferior hepatic TT involves the IVC below the diaphragm, type II involves the IVC above the diaphragm but outside the RA, and type III is TT above the diaphragm that reaches the RA. TT in the IVC or RA poses an increased risk of sudden cardiac arrest, liver failure, and pulmonary embolism. This TT classification is useful for selecting the operative procedure, especially for patients requiring CPB [14]. Considering the well-known potential intraoperative adverse effects of CPB, such as coagulation abnormalities with heparin, and postoperative complications, such as immunosuppression and cerebral infarction, its use should be considered carefully [4]. Several reports have described metastasis from a primary tumor after heart surgery using CPB. Hasegawa et al. [15] describe two mechanisms through which CPB might contribute to dissemination of tumor cells. First, tumor cells that contaminate the reservoir blood may spread through the arterial cannula. Second, disruption of homeostasis by CPB might liberate tumor cells that were spread preoperatively but whose migration or growth were suppressed by the immune system. As CPB is a complex technique with major systemic effects, surgical treatment with simple THVE should be performed if possible [4]. We previously reported that THVE was useful for hepatectomy in patients with tumor invasion into the hepatic vein and IVC or TT in the IVC [16]. Veno-venous bypass maintains cardiac venous return in cases where the tumor is localized to the IVC and suprahepatic IVC clamping is sufficient for safe removal of the tumor. In addition, Sakamoto et al. [4] mentioned that the RATT may be pulled downward into the IVC by mobilizing the liver caudally if the thrombus has only just entered the RA. By contrast, Ariizumi et al. [17] strongly advocated that cavo-atrial thrombectomy prior to hepatectomy for HCC with RATT should be performed under $\mathrm{CPB}$, because they experienced a pulmonary embolism due to RATT in a man with HCC who underwent hepatectomy prior to thrombectomy without CPB. CPB was crucial in providing the ability to incise the atrial and IVC walls to easily visualize and precisely extirpate the intravascular and intra-atrial parts of the tumor. However, in this case, the tumor was adherent to the wall of the IVC and atrium. Therefore, "pulling" the intra-atrial tumor en-bloc with the resected liver lobe without a sufficient viewpoint might have resulted in inappropriate resection and possible tearing and embolism of the tumor. In addition, to prevent potential intraoperative dissemination by intraoperative handling, Shirabe et al. [18] cited the benefit of thrombectomy before hepatic transection. Therefore, we decided to perform CPB for this patient to remove the RATT prior to the liver resection to prevent both pulmonary embolism and dissemination of malignant cells. THVE without CPB might scatter tumor cells during extirpation of the tumor or lead to incomplete removal of the TT if invasion to the wall is present [19]. Further, Wakayama et al. [6] experienced two cases of intra-IVC recurrence due to incomplete resection of TT on the IVC wall, so the IVC wall should be resected if invasion to the wall is suspected. Moreover, cardiocirculatory arrest seems to be superior to THVE in obtaining a better and exhaustive cleaning from the TT [20]. There are several surgical reports of HCC with RATT simultaneously resected under CPB. Our search of the English and Japanese literature revealed 28 cases of resection of HCC with RATT, in addition to the present case (Table 1) [3, 6, 17, 19-37]. We have found that the mean age is 59.62 \pm 10.49 years, which is younger than that of ordinary HCC patients, and only five patients are in seventies. There have been only two previous reports of cases in which thrombectomy under CPB was performed prior to hepatectomy. Liver recurrence and lung metastasis occurred in the 10 patients and in the 9 patients, respectively. Eleven patients including the present case are already deceased due to recurrence of HCC. Prior to our case, the longest one was 56-month survival reported by Yogita et al. [19]

Hepatectomy with extracorporeal circulation is normally employed only under specific conditions [26-28] because of the technical aspects associated with the procedure. Further, after hepatic resection performed during CPB, uncontrollable bleeding may occur as a result of coagulation abnormalities caused by cirrhosis and the use of heparin. In addition, a variety of complications, including disseminated intravascular coagulation and adult respiratory distress syndrome, may occur after CPB in patients with cirrhosis [29]. Therefore, CPB has not been widely performed for hepatectomy. Even if aggressive surgery for HCC with RATT is performed, the prognosis is not necessarily good. The present case describes the longest survival of a patient with HCC with RATT who underwent simultaneous resection of the liver and TT under CPB. The long survival in this case suggests that the heart-first approach could be better than the liver-first approach from an oncological point of view. In addition, the heart-first approach prevents not only sudden cardiac arrest and pulmonary embolism but also uncontrollable bleeding due to inflow obstruction by the ball valve effect. However, Ariizumi et al. [17] reported that a large amount of blood loss could occur during liver surgery due to heparinization. We also experienced a large volume of blood loss, probably due to heparin administration. 
Almost all HCC patients with TT formation in the vasculature experience recurrence after resection with curative intent [6]. The first recurrence most frequently occurs in the remnant liver, followed by multiple metastases in other organs, including the lungs [6]. As long as the recurrence is confined to the liver, several effective options are available, including repeated hepatectomy, RFA, and TACE [36]. Here, we adopted TACE because of the patient's preference.

Although thrombectomy alone has been performed in similar cases to avoid sudden death, the outcomes of those cases were poor [24]. Surgical resection is generally contraindicated for patients with unresectable metastates because incomplete resection is a decisive factor for poor prognosis. R1/2 resection has a negative impact on the prognosis, and R0 resection should be attempted [38]. Kasai et al. [39] altered their criteria for resection and performed preoperative hepatic arterial injection chemotherapy (HAIC) instead of up-front resection for patients with advanced HCC. Notably, preoperative HAIC seems to be associated with a reduced risk of recurrence [39]. Therefore, it could be a promising option for patients with HCC with RATT.

Intense follow-up should be performed during the patient's life, and multidisciplinary therapies are essential to achieve long-term survival of HCC patients. Our vigorous repeated treatments, including TACE, systemic chemotherapy, and radiotherapy, might have contributed to our patient's long survival. HCC with RATT is a very rare but critical entity, and aggressive surgical resection using CPB is the only method for obtaining curative treatment and long survival.

In conclusion, we report a case of HCC with RATT treated by aggressive surgery following multidisciplinary therapies after recurrence. Cavo-atrial thrombectomy prior to hepatectomy under CPB provides a safe, controlled approach for resection. Furthermore, CPB is conclusive for providing the ability to visualize the RATT, thereby ensuring satisfactory oncologic margins. This is the only reported case of HCC with RATT with a long survival time of approximately 15 years after surgery.

\section{Abbreviations}

CPB: cardiopulmonary bypass; HAIC: hepatic arterial injection chemotherapy; HCC: hepatocellular carcinoma; IVC: inferior vena cava; RA: right atrium; RFA: radiofrequency ablation; RHV: right hepatic vein; RHV: right hepatic vein; SVC: superior vena cava; TACE: transarterial chemoembolization; THVE: total hepatic vascular exclusion; TT: tumor thrombus

\section{Declarations}

\section{Ethics approval and consent to participate}

Not applicable

\section{Consent for publication}

Written informed consent was obtained from the patient's family for publication of this case report and accompanying images because the patient is deceased.

\section{Availability of data and materials}

The authors declare that all the data in this article are available within the article.

\section{Competing interests}

The authors declare that they have no competing interests.

\section{Funding}

None of the authors received any funding.

\section{Authors' contributions}

YN, TK, and TH participated in a conference to plan the surgery and performed the surgery. TO performed the histological examination of the liver tumor and thrombus. YN and TK made substantial contributions to the conception and design of the study. YN, TK, TH, and TO analyzed and interpreted the data. YN was a major contributor to the writing of the manuscript. All authors have read and approved the final manuscript.

\section{Acknowledgements}

The authors would like to thank Editage (www.editage.com) for English language editing.

\section{References}

1. Lafaro KJ, Demirjian AN, Pawlik TM. Epidemiology of hepatocellular carcinoma. Surg Oncol Clin N Am. 2015; 24: 1-17.

2. Numan L, Asif S, Abughanimeh O. Hepatocellular carcinoma with tumor thrombus extending from the portal vein to the right atrium. Cureus $11(5)$ :e4689. doi 10.7759/cureus.4689.

3. Florman S, Weaver M, Primeaux P, Killackey M, Sierra R, Gomez S, et al. Aggressive resection of hepatocellular carcinoma with right atrial involvement. Ann Surg. 2009; 75: 1104-8. 
4. Sakamoto K, Nagano H. Outcomes of surgery for hepatocellular carcinoma with tumor thrombus in the inferior vena cava or right atrium. Surgery Today. 2018; 48: 819-24.

5. Wang Y, Yuan L, Ge RL, Sun Y, Wei G. Survival benefit of surgical treatment for hepatocellular carcinoma with inferior vena cava/right atrium tumor thrombus: results of a retrospective cohort study. Ann Surg Oncol. 2013; 20: 914-22

6. Wakayama K, Kamiyama T, Yokoo H, Kakisaka T, Kamachi H, Tsuruga Y, et al. Surgical management of hepatocellular carcinoma with tumor thrombi in the inferior vena cava or right atrium. World J Surg Oncol. 2013; 11: 259.

7. Chun YH, Ahn SH, Park JY, Kim-do Y, Han KH, Chon CY, et al. Clinical characteristics and treatment outcomes of hepatocellular carcinoma with inferior vena cava/heart invasion. Anticancer Res. 2011;31: 4641-6.

8. Matsukuma S, Eguchi H, Wada H, Noda T, Shindo Y, Tokumitsu Y, et al. Liver resection with thrombectomy for patients with hepatocellular carcinoma and tumor thrombus in the inferior vena cava or right atrium. BJS Open 2020 doi:10.1002/bjs5.50258.

9. Liver Cancer Study Group of Japan. The general rules for the clinical and pathological study of primary liver cancer, the $6^{\text {th }}$ revised version. Tokyo: Kanehara Syuppan; 2019

10. Heimbach JK, Kulik LM, Finn RS, Sirlin CB, Abecassis MM, Roberts LR, et al. AASLD guidelines for the treatment of hepatocellular carcinoma. Hapatology. 2018; 67: 358-80.

11. Forner A, Reig ME, de Lope CR, Bruix J. Current strategy for staging and treatment: The BCLC update and future prospects. Semin Liver Dis. 2010; 30: 6174.

12. Llovet JM, Ricci S, Mazzaferro V, Hilgard P, Gane E, Blanc JF, et al. Sorafenib in advanced hepatocellular carcinoma. N Engl J Med. 2008; 359 : 378-90.

13. Bruix J, Raoul JL, Sherman M, Mazzaferro V, Bolondi L, Craxi A, et al. Efficacy and safety of sorafenib in patients with advanced hepatocellular carcinoma: subanalyses of a phase III trial. J Hepatol 2012; 57: 821-9.

14. Li A-J, Zhou W-P, Lin C, Lang X-L, Wang Z-G, Yang X-Y, et al. Surgical treatment of hepatocellular carcinoma with inferior vena cava tumor thrombus: a new classification for surgical guidance. Hepatobiliary Pancreat Dis Int. 2013;12: 263-9.

15. Hasegawa S, Otake Y, Bando T, Cho H, Inui K, Wada H. Pulmonary dissemination of tumor cells after extended resection of thyroid carcinoma with cardiopulmonary bypass. J Thorac Cardiovasc Surg. 2002; 124: 635-636

16. Kusano T. Tamai O. Miyazato H, Isa T, Muto Y, Furukawa M. et al. Extracorporeal bypass using a centrifugal pump during resection of malignant liver tumors. Hepatogastroenterology. 1999; 46: 2483-9.

17. Ariizumi S, Kikuchi C, Tokitou F, Yamashita S, Kotera Y, Omori A, et al. Cavo-atrial thrombectomy prior to hepatectomy for hepatocellular carcinoma with tumor thrombus in the right atrium: a case report. Surgical Case Reports. 2019; 5: 57.

18. Shirabe K, Shimada M, Tsujita E, et al. Thrombectomy before hepatic resection for hepatocellular carcinoma with a tumor thrombus extending to the inferior vena cava. Int Surg. 2001; 86: 141-3.

19. Yogita S, Tashiro S, Harada M, Kitagawa T, Kato I. Hepatocelular carcinoma with extension into the right atrium: report of a successful liver resection by hepatic vascular exclusion using cardiopulmonary bypass. J Med Invest. 2000; 47: 155-60.

20. Pesi B, Giudici F, Moraldi L, Montesi G, Romagnoli S, Pinelli F, et al. Hepatocellular carcinoma on cirrhosis complicated with tumoral thrombi extended to the right atrium: results in three cases treated with major hepatectomy and thrombectomy under hypothermic cardiocircular arrest and literature review. World J Surg.Oncol. 2016; 14: 83.

21. Onitsuka A, Hirose H, Ozeki Y, Hino A, Mori Y, Murakawa S, et al. Hepatoma with growth in right atrium: report of successful resection. Dig Surg. 1990; 7: $57-60$.

22. Tsuzuki T, Kawada K, Ueda M, Takahashi S, Nakayasu K, Ishii H, et al. Hepatocellular carcinoma with tumor thrombus extending into the right atrium report of a successful resection. (in Japanese with English abstract) Jpn J Gastroenterol Surg. 1991; 24: 2236-40.

23. Fujisaki M, Kurihara E, Kikuchi K, Nishikawa K, Uematsu Y. Hepatocellular carcinoma with tumor thrombus extending into the right atrium: report of a successful resection with the use of cardiopulmonary bypass. Surgery. 1991; 109: 214-9.

24. Yokoi Y, Hachiya T, Kurachi K, Okamoto K, Tsuchiya Y, Okumura T, et al. Resection of hepatocellular carcinoma with tumor thrombus extending into the right atrium. (in Japanese with English abstract) Jpn J Gastroenterol Surg. 2000; 33: 1507-11.

25. Wu CC, Hseih S, Ho WM, Tang JS, Liu TJ, P'eng FK et al. Surgical treatment for recurrent hepatocellular carcinoma with tumor thrombi in right atrium using cardiopulmonary bypass and deep hypothermic circulatory arrest. J Surg Oncol. 2000; 74: 227-31.

26. Miyazawa M, Torii T, Asano H, Yamada M, Toshimitsu Y, Shinozuka N, et al. Does a surgery for hepatocellular carcinoma with tumor thrombus highly occupying in the right atrium have significance? A case report and review of the literature. Hepatogastroenterology. 2005; 52: 212-6.

27. Sugimoto H, Inoue S, Mori T, Hirota M, Takeda S, Kaneko T, et al. Tumor thrombus removal with hepatic resection using cardiopulmonary bypass in a patient with hepatocellular carcinoma extending into right atrium. (in Japanese with English abstract) Jpn J Gastroenterol Surg. $2004 ; 37: 1737-42$.

28. Tani Y, Nakagawa T, Kamiyama T, Nakanishi K, Fukumori D, Kamachi H, et Hepatocellular carcinoma extending into right atrium was resected successfully using cardio-pulmonary bypass. Jpn J Gastroenterol Surg. 2006; 39: 306-11.

29. Ohwada S, Takahashi T, Tsutsumi H, Kawate S, Ohki S, Hamada K. Hepatocellular carcinoma with a tumor thrombus extending to the tricuspid valve: report of a successful en bloc resection. Hepatogastroenterology; 2008; 55: 903-6.

30. Sasaki Y, Yamada A, Goto K, Takami H. Hepatectomy with the use of extracorporeal circulation for hepatic cancer extending into the inferior vena cava or the right atrium. (in Japanese) Geka. 2008; 70: 178-82.

31. Leo F, Rapisarda F, Stefano PL, Batignani G, Leo F, et al. Cavo-atrial thrombectomy combined with left hemi-hepatectomy for vascular from hepatocellular carcinoma on diseased liver under hypothermic cardio-circulatory arrest. Interact Cardiovasc Surg. 2010; 10: 473-5.

Page 5/10 
32. Inoue Y, Hayashi M, Katsumata T, Shibayama Y, Tanigawa N. Hepatocellular carcinoma with right atrial tumor thrombus: report of a case. Surg Today. 2011; 41: 1122-9.

33. Li SS, Jian LL, Gang PB, Ando KM, Ming LD, Li SS, et al. Removal of hepatocellular carcinoma extending into the right atrium with extracorporeal circulation. Hepatogastrroenterology. 2012; 59: 1591-3.

34. Ohta M, Nakanishi C, Kawagishi N, Hara Y, Maida K, Kashiwadate T, et al. Surgical resection of recurrent extrahepatic hepatocellular carcinoma with tumor thrombus extending into the right atrium under cardiopulmonary bypass: a case report and review of the literature. Surgical Case Reports. $2016 ; 2: 110$.

35. Tsang J, Chan A, Chok K, Tsang F, Lo CM. Combined cavo-atrial thrombectomy and hepatectomy in hepatocellular carcinoma. Hepatobiliary Pancreat Dis Int. 2017; 16: 329-33.

36. Zhang Y, Wu Z, Wang K, Han S, Li C, Li X. Long-term survival after anterior approach right hepatectomy combined with inferior vena cava thrombectomy using trans-diaphragmatic intrapericardial inferior vena cava occlusion: a case report and review of the literature. BMC Surgery. $2019 ; 19: 122$.

37. Luo X, Zhang B, Dong S, Zhang B, Chen X. Hepatocellular carcinoma with tumor thrombus occupying the right atrium and portal vein-a case report and literature review. Medicine. 2015; 94:1-5.

38. Kokudo T, Hasega.wa K, Yamamoto S, Shindoh J, Takemura N, Aoki T, et al. Surgical treatment of hepatocellular carcinoma associated with hepatic vein tumor thrombosis. J Hepatol. 2014; 61: 583-8.

39. Kasai Y, Hatano E, Seo S, Taura K, Yasuchika K, Okajima H, et al. Proposal of selection criteria for operative resection of hepatocellular carcinoma with inferior vena cava tumor thrombus incorporating hepatic artery infusion chemotherapy. Surgery. 2017; 162: $742-51$.

\section{Tables}

Table 1. Reported cases of hepatocellular carcinoma and tumor thrombus in the right atrium simultaneously resected under cardiopulmonary bypass. 


\begin{tabular}{|c|c|c|c|c|c|c|c|c|c|c|c|}
\hline & Author & Year & Age/Sex & $\begin{array}{l}\text { Size of } \\
\text { HCC } \\
\text { (cm) }\end{array}$ & $\begin{array}{l}\text { Liver or } \\
\text { Heart } \\
\text { Surgery } \\
\text { First }\end{array}$ & $\begin{array}{l}\text { Cardiac } \\
\text { Arrest }\end{array}$ & $\begin{array}{l}\text { Treatment } \\
\text { Technique }\end{array}$ & Additional Treatment & $\begin{array}{l}\text { Blood } \\
\text { Loss }\end{array}$ & $\begin{array}{l}\text { Operation } \\
\text { Time }\end{array}$ & Com \\
\hline 1 & $\begin{array}{l}\text { Onitsuka } \\
\text { [21] }\end{array}$ & 1990 & 59/Male & 15 & $\begin{array}{l}\text { Liver } \\
\text { First }\end{array}$ & No Arrest & Left HR & No & N.D. & N.D. & No \\
\hline 2 & Tuzuki [22] & 1991 & 57/Male & 5 & $\begin{array}{l}\text { Liver } \\
\text { First }\end{array}$ & No Arrest & $\begin{array}{l}\text { S4 } \\
\text { segmentectomy }\end{array}$ & Chemotherapy & 6720 & $\begin{array}{l}13 \mathrm{~h} 52 \\
\min \end{array}$ & DIC \\
\hline 3 & $\begin{array}{l}\text { Fujisaki } \\
\text { [232] }\end{array}$ & 1991 & 38/Female & 8.5 & $\begin{array}{l}\text { Liver } \\
\text { First }\end{array}$ & Arrest & Left HR & No & 9400 & $\begin{array}{l}14 \text { h } 54 \\
\text { min }\end{array}$ & No \\
\hline 4 & Yokoi [24] & 2000 & 54/Male & 7 & $\begin{array}{l}\text { Liver } \\
\text { First }\end{array}$ & N.D. & Left HR & TACE & 14000 & $\begin{array}{l}8 \mathrm{~h} 55 \\
\min \end{array}$ & Bleec \\
\hline 5 & Wu [25] & 2000 & 42/Male & 1.5 & $\begin{array}{l}\text { Liver } \\
\text { First }\end{array}$ & Arrest & $\begin{array}{l}\text { Partial } \\
\text { Resection }\end{array}$ & TACE & 7000 & $\begin{array}{l}11 \mathrm{~h} 12 \\
\min \end{array}$ & No \\
\hline 6 & Yogita [19] & 2000 & 61/Male & 3 & $\begin{array}{l}\text { Liver } \\
\text { First }\end{array}$ & No Arrest & Left HR & No & 2910 & $\begin{array}{l}11 \mathrm{~h} 20 \\
\min \end{array}$ & No \\
\hline 7 & $\begin{array}{l}\text { Miyazawa } \\
{[26]}\end{array}$ & 2004 & 55/Male & 7 & $\begin{array}{l}\text { Liver } \\
\text { First }\end{array}$ & N.D. & Right HR & No & 4500 & $\begin{array}{l}6 \mathrm{~h} 30 \\
\min \end{array}$ & No \\
\hline 8 & $\begin{array}{l}\text { Sugimoto } \\
\text { [27] }\end{array}$ & 2004 & 55/Male & 14 & $\begin{array}{l}\text { Heart } \\
\text { First }\end{array}$ & No Arrest & Left HR & TACE & 3735 & $\begin{array}{l}8 \mathrm{~h} 20 \\
\min \end{array}$ & No \\
\hline 9 & Tani [28] & 2006 & 68/Male & 10 & $\begin{array}{l}\text { Liver } \\
\text { First }\end{array}$ & N.D. & Right HR & TACE & 2750 & $\begin{array}{l}7 \mathrm{~h} 29 \\
\min \end{array}$ & No \\
\hline 10 & $\begin{array}{l}\text { Ohwada } \\
\text { [29] }\end{array}$ & 2008 & 77/Female & 10 & $\begin{array}{l}\text { Liver } \\
\text { First }\end{array}$ & Arrest & Left HR & No & 1078 & $11 \mathrm{~h}$ & No \\
\hline 11 & Sasaki [30] & 2008 & 60/ Male & N.D. & $\begin{array}{l}\text { Liver } \\
\text { First }\end{array}$ & Arrest & Left HR & N.D. & N.D. & N.D. & N.D. \\
\hline 12 & Florman [3] & 2009 & 55/Male & 18 & $\begin{array}{l}\text { Liver } \\
\text { First }\end{array}$ & Arrest & Left HR & No & N.D. & $6 \mathrm{~h}$ & No \\
\hline 13 & Leo [31] & 2010 & 45/Male & N.D. & $\begin{array}{l}\text { Liver } \\
\text { First }\end{array}$ & $\begin{array}{l}\text { Heart } \\
\text { Fibrillated }\end{array}$ & Left HR & No & N.D. & N.D. & $\begin{array}{l}\text { Pleur } \\
\text { Effus }\end{array}$ \\
\hline 14 & Inoue [32] & 2011 & 67/Male & 5 & $\begin{array}{l}\text { Liver } \\
\text { First }\end{array}$ & No Arrest & Left HR & No & 4180 & N.D. & No \\
\hline 15 & Li [33] & 2012 & 64/Male & 5.3 & $\begin{array}{l}\text { Liver } \\
\text { First }\end{array}$ & Arrest & $\begin{array}{l}\text { Posterior } \\
\text { Sectionectomy }\end{array}$ & No & N.D. & $\begin{array}{l}6 \mathrm{~h} 45 \\
\min \end{array}$ & No \\
\hline 16 & Li [33] & 2012 & 44/Male & 10.7 & $\begin{array}{l}\text { Liver } \\
\text { First }\end{array}$ & No Arrest & Right HR & $\begin{array}{l}\text { TACE, } \\
\text { Immunochemotherapy, } \\
\text { Local ablation }\end{array}$ & 1200 & $6 \mathrm{~h}$ & $\begin{array}{l}\text { Pleur } \\
\text { Effus }\end{array}$ \\
\hline 17 & $\begin{array}{l}\text { Wakayama } \\
\text { [6] }\end{array}$ & 2013 & 68/Male & & $\begin{array}{l}\text { Liver } \\
\text { First }\end{array}$ & N.D. & Right HR & No & & & \\
\hline 18 & $\begin{array}{l}\text { Wakayama } \\
\text { [6] }\end{array}$ & 2013 & 70/Male & & $\begin{array}{l}\text { Liver } \\
\text { First }\end{array}$ & N.D. & Right HR & Chemotherapy & & & \\
\hline 19 & $\begin{array}{l}\text { Wakayama } \\
{[6]}\end{array}$ & 2013 & 66/Male & $\begin{array}{l}\text { Average } \\
\pm \mathrm{SD}\end{array}$ & $\begin{array}{l}\text { Liver } \\
\text { First }\end{array}$ & N.D. & Right HR & Chemotherapy & $\begin{array}{l}\text { Average } \\
\pm S D\end{array}$ & $\begin{array}{l}\text { Average } \\
\pm \mathrm{SD}\end{array}$ & \\
\hline 20 & $\begin{array}{l}\text { Wakayama } \\
{[6]}\end{array}$ & 2013 & 51/Male & $\begin{array}{l}11.8 \pm \\
4.3\end{array}$ & $\begin{array}{l}\text { Liver } \\
\text { First }\end{array}$ & N.D. & Left HR & Chemotherapy & $\begin{array}{l}6540 \pm \\
5404\end{array}$ & $\begin{array}{l}10 \mathrm{~h} 8 \\
\min \\
\pm 169 \\
\min \end{array}$ & $\begin{array}{l}\text { Af 1, } \\
\text { ARF }\end{array}$ \\
\hline 21 & $\begin{array}{l}\text { Wakayama } \\
\text { [6] }\end{array}$ & 2013 & 59/Male & & $\begin{array}{l}\text { Liver } \\
\text { First }\end{array}$ & N.D. & Left HR & No & & & \\
\hline 22 & $\begin{array}{l}\text { Wakayama } \\
\text { [6] }\end{array}$ & 2013 & 65/Male & & $\begin{array}{l}\text { Liver } \\
\text { First }\end{array}$ & N.D. & Sectionectomy & Chemotherapy & & & \\
\hline 23 & Ohta [34] & 2016 & 60/Male & N.D. & $\begin{array}{l}\text { Liver } \\
\text { First }\end{array}$ & No Arrest & $\begin{array}{l}\text { Diaphragmatic } \\
\text { Tumorectomy }\end{array}$ & Sorafenib & 5881 & $\begin{array}{l}12 \mathrm{~h} 19 \\
\min \end{array}$ & No \\
\hline 24 & Pesi [20] & 2016 & 51/Male & 6.5 & $\begin{array}{l}\text { Liver } \\
\text { First }\end{array}$ & Arrest & Left HR & N.D. & & & \\
\hline 25 & Pesi [20] & 2016 & 73/Male & 4.5 & $\begin{array}{l}\text { Liver } \\
\text { First }\end{array}$ & Arrest & Left HR & N.D. & $\begin{array}{l}\text { Average } \\
\pm \mathrm{SD}\end{array}$ & $\begin{array}{l}\text { Average } \\
\pm \mathrm{SD}\end{array}$ & $\begin{array}{l}\text { Pleur } \\
\text { Effus } \\
\text { Ascit }\end{array}$ \\
\hline 26 & Pesi [20] & 2016 & 76/Female & 14 & Liver & Arrest & Right HR & N.D. & $926.6 \pm$ & 5 h 36 & \\
\hline
\end{tabular}




\begin{tabular}{|c|c|c|c|c|c|c|c|c|c|c|c|}
\hline & & & & & First & & & & 325.9 & $\min _{\min } \pm 66$ & \\
\hline 27 & Tsang [36] & 2017 & 47/Male & 19.6 & $\begin{array}{l}\text { Liver } \\
\text { First }\end{array}$ & No Arrest & Right HR & Chemotherapy & 30000 & N.D. & No \\
\hline 28 & $\begin{array}{l}\text { Ariizumi } \\
\text { [17] }\end{array}$ & 2019 & 75/Female & 21 & $\begin{array}{l}\text { Heart } \\
\text { First }\end{array}$ & $\begin{array}{l}\text { Heart } \\
\text { Fibrillation }\end{array}$ & Right HR & N.D. & 8200 & $9 \mathrm{~h}$ & No \\
\hline 29 & $\begin{array}{l}\text { Present } \\
\text { Case }\end{array}$ & & 67/Male & 6 & $\begin{array}{l}\text { Heart } \\
\text { First }\end{array}$ & Arrest & Right HR & $\begin{array}{l}\text { TACE, Chemotharapy } \\
\text { Radiotherapy }\end{array}$ & 7267 & $\begin{array}{l}10 \mathrm{~h} 48 \\
\min \end{array}$ & $\begin{array}{l}\text { Pleur } \\
\text { Effus }\end{array}$ \\
\hline
\end{tabular}

Ad: adrenal gland, Af: atrial fibrillation, ARF: acute renal failure, DIC: disseminated intravascular coagulation, HCC: hepatocellular carcinoma, HR: hepatic resection, LN: lymph node, N.D.: not described, SD: standard deviation, TACE: transcatheter arterial chemoembolizati

\section{Figures}


Figure 1

Preoperative imaging studies. a Enhanced CT showing a tumor (black arrow), $6.5 \mathrm{~cm}$ in diameter, in the right lobe of the liver and tumor thrombus (white arrow) in the IVC. b Enhanced CT showing a tumor thrombus (white arrow) in the right atrium. c Echocardiography revealed a tumor thrombus (white arrow) in the right atrium. CT: computed tomography; IVC: inferior vena cava

Intraoperative photograph. a A tumor thrombus in the RA and IVC was removed under cardiopulmonary bypass with cardiac arrest. The RA and IVC were incised longitudinally, and the tumor thrombus (white arrow) was excised under direct vision. b Right lobectomy of the liver was performed, and the incision over the RA and IVC was closed longitudinally with a running suture. RA: right atrium; IVC: inferior vena cava
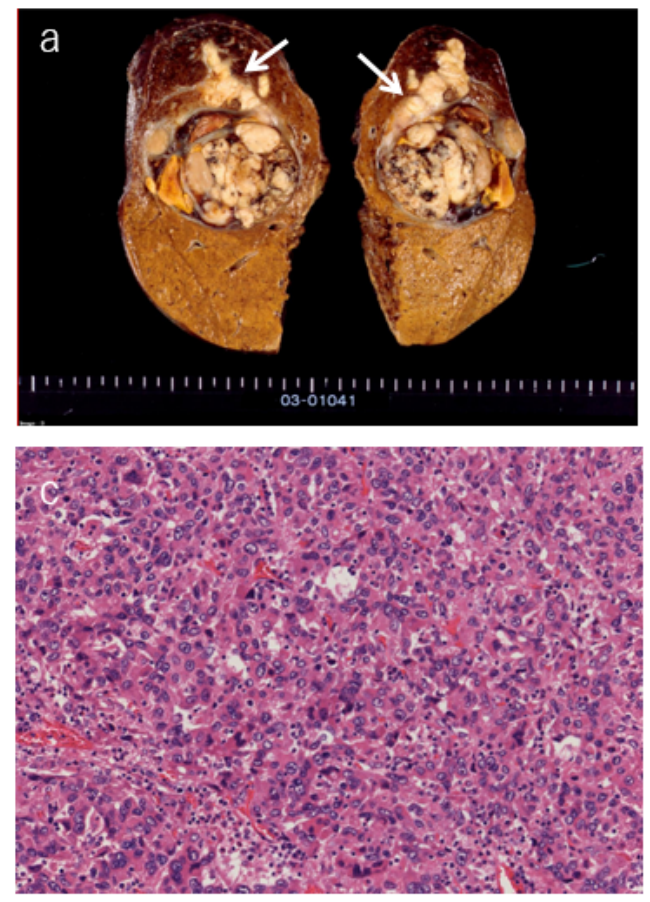


\section{Figure 3}

Pathology. a The resected specimen. The main liver tumor $(7.0 \times 6.5 \times 6.0 \mathrm{~cm})$ was an encapsulated hepatocellular carcinoma at segments 7 and 8 . There was a tumor thrombus (white arrow) in the right hepatic vein. b Excised tumor thrombus in the right atrium and IVC. c Photomicrograph of the main tumor. The tumor was diagnosed as an Edmondson grade III carcinoma. The cells were arranged in solid sheets and had relatively uniform nuclei and eosinophilic cytoplasm. The tumor was composed of an aggregation of anaplastic cells with an irregular, large nucleus. (Hematoxylin-eosin stain, original magnification 200x) d The tumor thrombus showed organizational change and contained live tumor cells that were consistent with the primary tumor (inset). (Hematoxylineosin stain, original magnification 10x [inset 200x]) IVC: inferior vena cava
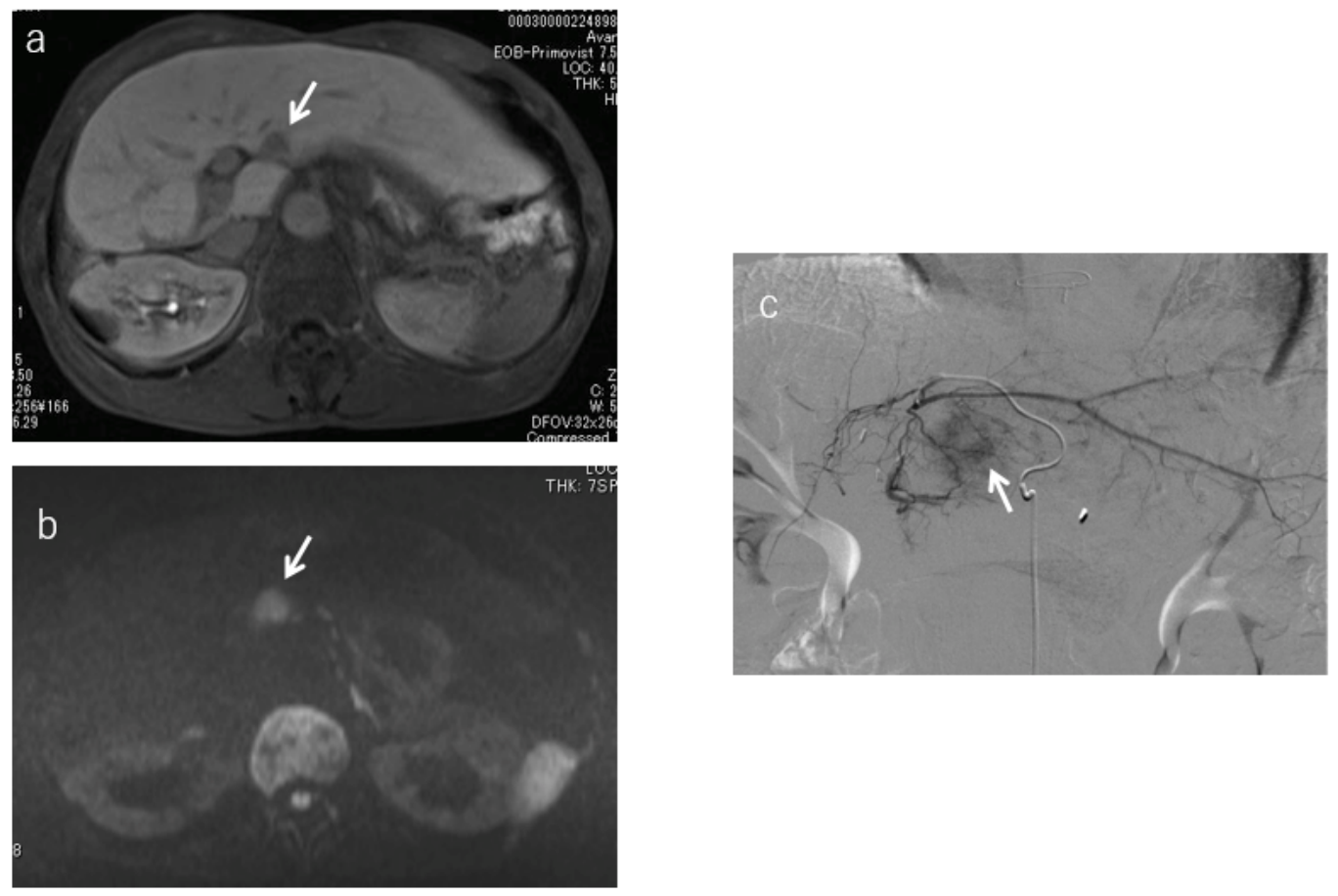

\section{Figure 4}

Recurrent tumor in the remnant liver. MRI showing the tumor at segment 2 of the liver, which had low signal intensity on T1-weighted imaging (a) and high signal intensity on diffusion-weighted imaging (b). (c) The tumor was hypervascular and was treated by transcatheter arterial chemoembolization. MRI: 
magnetic resonance imaging

Page 10/10 